\title{
Influence of Non-Thermal Atmospheric Pressure Plasma Jet on Extracellular Activity of $\alpha$-Amylase in Aspergillus oryzae
}

\author{
Mayura Veerana ${ }^{1}$ (D), Eun Ha Choi ${ }^{1,2}$ (D) and Gyungsoon Park ${ }^{1,2, *}$ \\ 1 Department of Plasma Bioscience and Display, Kwangwoon University, Seoul 01897, Korea; \\ mayuraveerana@gmail.com (M.V.); ehchoi@kw.ac.kr (E.H.C.) \\ 2 Department of Electrical and Biological Physics, Kwangwoon University, Seoul 01897, Korea \\ * Correspondence: gyungp@kw.ac.kr; Tel.: +82-2-940-8324
}

Citation: Veerana, M.; Choi, E.H.; Park, G. Influence of Non-Thermal Atmospheric Pressure Plasma Jet on Extracellular Activity of $\alpha$-Amylase in Aspergillus oryzae. Appl. Sci. 2021, 11, 691. https://doi.org/10.3390/ app11020691

Received: 4 December 2020 Accepted: 8 January 2021

Published: 12 January 2021

Publisher's Note: MDPI stays neutral with regard to jurisdictional clai$\mathrm{ms}$ in published maps and institutional affiliations.

Copyright: (C) 2021 by the authors. Licensee MDPI, Basel, Switzerland. This article is an open access article distributed under the terms and conditions of the Creative Commons Attribution (CC BY) license (https:// creativecommons.org/licenses/by/ $4.0 /)$.

\begin{abstract}
In a previous study, we found that plasma can enhance spore germination and $\alpha$-amylase secretion in A. oryzae, a beneficial fungus used in fermentation. To confirm this, in the current study, we investigated the effects of plasma on development and $\alpha$-amylase secretion using an enlarged sample size and a different plasma source: a plasma jet. There was a $\sim 10 \%(p<0.01)$ increase in spore germination upon non-thermal atmospheric pressure plasma jet (NTAPPJ) treatment for 5 min and $10 \mathrm{~min}$, as compared with the control (no plasma treatment). The activity of $\alpha$-amylase detected in potato dextrose broth (PDB) media during incubation was significantly elevated in plasma-treated samples, with a more obvious increase upon $10 \mathrm{~min}$ and $15 \mathrm{~min}$ treatments and 24-96 h incubation periods. The levels of the oxidation reduction potential (ORP) and $\mathrm{NO}_{X}$ (nitrogen oxide species) were higher in the plasma-treated samples than in the control samples, suggesting that these two variables could serve as standard indicators for enhancing $\alpha$-amylase activity after plasma treatment. Genome sequencing analysis showed approximately $0.0016-0.0017 \%$ variations (changes in 596-655 base pairs out of a total of $37,912,014$ base pairs) in the genomic DNA sequence of $A$. oryzae after plasma treatment. Our results suggest that NATPPJ can enhance the spore germination and extracellular activity of $\alpha$-amylase, probably by increasing the levels of ORP and $\mathrm{NO}_{X}$ to an optimum level.
\end{abstract}

Keywords: Aspergillus oryzae; $\alpha$-amylase; enzyme secretion; non-thermal atmospheric pressure plasma

\section{Introduction}

At present, the demand for enzymes is increasing in different industrial activities, such as chemistry, food, textiles, and pharmaceuticals. In particular, the food industry is continuously demanding enzymes for use in fermentation and other processes. $\alpha$-amylase is one such enzyme with high demand in starch-processing industries, such as those involved in the production of glucose syrups, bread, and alcoholic beverages, because it is used for the hydrolysis of starch into simple sugar components. In addition, $\alpha$-amylase is widely used as an additive for making soaps, detergents, and animal feeds, as well as in treating paper and textiles [1]. To be used on an industrial scale, the efficient and environmentally friendly production of enzymes is essential. Wild-type and genetically modified microorganisms have been considered good producers of food enzymes because those are more stable and steadily active, compared with plant and animal enzymes [2-4]. However, there are still many technical barriers that have to be overcome for the industrialscale production of enzymes by microorganisms, such as low levels of enzyme production and secretion, contamination of enzymes with other components, and the instability of enzymes under certain conditions. Therefore, technology development is necessary to improve the efficiency of enzyme production and to ensure that the process is simple, fast, safe, and involves a low cost.

Non-thermal atmospheric pressure plasma (NTAPP) is a cutting-edge technology that has been gaining attention for numerous applications, including environmental, medicinal, agricultural, decontamination, and food bioprocessing [5-8]. Plasma, an ionized gas 
that is known as the fourth state of matter, can generate free electrons, neutral reactive oxygen and nitrogen species (RONS), charged gas ions, and active gas species [9]. Since RONS are known to produce deactivating and activating effects, depending on their concentration, plasma treatment can also possibly generate these dual effects based on the treatment dose. The application of NTAPP to microorganisms has been mostly focused on the deactivation of microbes harmful to human life [10-12]. In food industries, NTAPP has proven to be extremely useful for food preservation by mediating the deactivation of microorganisms, including pathogens, spoilage fungi, and bacterial spores [13]. The plasma-mediated activation of vitality and enzyme production in microorganisms has recently been reported in several studies [14-18]. Since a broad spectrum of plasma effects can be expected, depending on factors such as the types of microorganisms, dosage of plasma, and RONS produced, NTAPP is a potential technology that can be applied to improve enzyme production and the vitality of beneficial microorganisms. However, the fundamental processes involved in the effects of NTAPP on the activation of microbial cells are poorly understood.

In a previous study, we observed that there was an increase in the germination and secretion of $\alpha$-amylase by A. oryzae post plasma treatment [18]. As a continuous investigation, in the present study, we examined the effect of plasma on the germination, growth, and $\alpha$-amylase production in A. oryzae by using a scaled-up sample size and NTAPP jet (NTAPPJ). A. oryzae, considered to be generally recognized as safe (GRAS), is a good model microbe for studying the production of food enzymes, because it is known to have the capability of producing and secreting high-value industrial enzymes [19-21].

\section{Materials and Methods}

\subsection{Fungal Strain and Culture Conditions Used in this Study}

The fermenting fungus A. oryzae (strain KACC47488) used in this study was kindly provided by the Korean Agriculture Type Collection at the National Agrobiodiversity Center (Wanju-gun, Jeollabuk-do, Korea). The fungus was maintained on a potato dextrose agar (PDA) medium (KisanBio, Seoul, Korea) at $30^{\circ} \mathrm{C}$ in the dark. In the experiment, PDA or potato dextrose broth (PDB) was used to culture the fungus at $30^{\circ} \mathrm{C}$.

\subsection{Plasma Device and Treatment of Fungal Spores}

Spores of A. oryzae were treated with an NTAPP jet (Figure 1). The electrode structure and physical properties of the plasma jet device were described in a previous study [22]. The feeding gas was ambient air, provided at a flow rate of $1.5 \mathrm{~L} \mathrm{~min}^{-1}$. Approximately $0.05 \mathrm{~W}$ of plasma energy was generated.

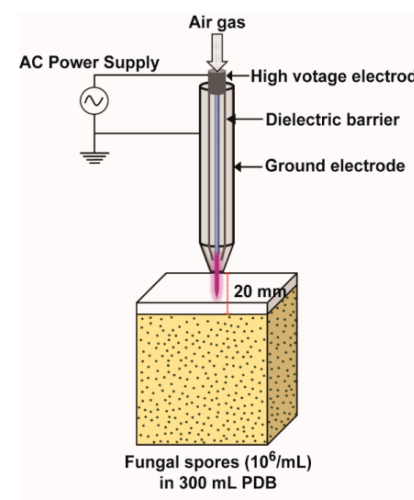

(a)

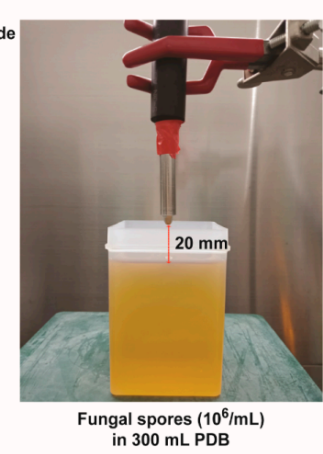

(b)

Figure 1. Non-thermal atmospheric pressure plasma jet device. (a) Schematic view of the plasma jet device and the experimental set-up for fungal spore treatment with plasma. (b) Photograph of treatment of the fungal spore suspension with the plasma jet. 
A. oryzae spores were harvested by adding $15 \mathrm{~mL}$ of sterile phosphate-buffered saline (PBS) to 1-week-old culture plates and scraping the fungal mycelia using a spreader. The fungal suspension was filtered through 4 layers of sterile miracloth (Calbiochem, Darmstadt, Germany), and the filtrate was centrifuged at $3134 \times g$ for $5 \mathrm{~min}$. After the supernatant was discarded, the spore pellet was resuspended in a new PDB solution such that the final concentration was $10^{6}$ spores per $\mathrm{mL}$. Then, $300 \mathrm{~mL}$ of the spore suspension $\left(10^{6}\right.$ fungal spores per $\left.\mathrm{mL}\right)$ was placed in a square jar $(72 \mathrm{~mm} \times 72 \mathrm{~mm} \times 100 \mathrm{~mm})$. The fungal spores were treated with an NTAPP jet at a distance of $20 \mathrm{~mm}$ for $5,10,15$, and $20 \mathrm{~min}$ (Figure 1). Untreated spores (0 $\mathrm{min}$ ) were used as a control. Following treatment, the spore suspension $(50 \mathrm{~mL})$ was transferred to a $100 \mathrm{~mL}$ Erlenmeyer flask and incubated at $30^{\circ} \mathrm{C}$ while shaken for the indicated times.

\subsection{Fungal Germination and Growth Measurement}

Following treatment with the plasma jet, the spore suspension was serially diluted using a PBS solution, and $100 \mu \mathrm{L}$ of the diluted suspension was spread onto PDA plates. The plates were incubated at $30^{\circ} \mathrm{C}$ in the dark for 2 days, and following this, the number of colonies (germinated spores) was counted. The relative spore germination percentage, compared to that of the control, was calculated as follows: relative germination $(\%)=$ (number of germinated spores post plasma treatment/number of germinated spores in the untreated control) $\times 100$. The average germination percentage was calculated from three replicate plates per experiment, and the experiment itself was repeated two times.

For growth, the treated fungal spores (50 $\mathrm{mL}$ in an Erlenmeyer flask) were incubated at $30^{\circ} \mathrm{C}$ while shaken for $48 \mathrm{~h}$. The fungal mycelia were collected by filtering the fungal culture through 4 layers of sterile miracloth. After the water was squeezed out, the fungal mycelia were maintained at $60{ }^{\circ} \mathrm{C}$ until completely dry. The weight of the completely dried mycelial mass was then measured. The average dry weight was assessed from three replicates per experiment, and the experiment itself was repeated three times.

\subsection{Measurement of the Total Protein Level and $\alpha$-Amylase Activity in the Media}

Following treatment with the plasma jet, the spore suspension $(50 \mathrm{~mL})$ was transferred to a $100 \mathrm{~mL}$ Erlenmeyer flask and incubated at $30^{\circ} \mathrm{C}$ while shaken for the indicated times. At each time point, only cultured media was collected, and the total protein concentration was determined using the Bradford protein assay kit (Bio-Rad, Hercules, CA, USA).

For measuring the $\alpha$-amylase activity, the diluted culture medium $(100 \mu \mathrm{L})$ was added to a reaction mixture containing $100 \mu \mathrm{L}$ of $1 \%(w / v)$ soluble starch in a $0.1 \mathrm{M}$ acetate buffer (pH 5.6). The reaction mixture was incubated at $50{ }^{\circ} \mathrm{C}$ for $30 \mathrm{~min}$ [23], and the liberated reducing sugars (product: maltose equivalent) were measured using the 3,5-dinitrosalicylic acid method [24]. A separate blank (cultured media without soluble starch) was used for each sample to eliminate the non-enzymatic release of sugars. Maltose was used to construct a standard curve. One unit (U) of amylase activity was defined as the amount of the enzyme that released $1 \mu \mathrm{g}$ of maltose (as a reducing sugar equivalent) per $\mathrm{mL}$ per minute under the assay conditions. Specific activity was expressed as amylase activity (U) per mg of protein.

2.5. Measurement of $\mathrm{H}_{2} \mathrm{O}_{2}, \mathrm{NO}_{\mathrm{X}}, \mathrm{NO}_{2}{ }^{-}$, and $\mathrm{NO}_{3}{ }^{-}$Levels, Oxidation Reduction Potential, and $\mathrm{pH}$ in PDB Media

PDB $(300 \mathrm{~mL})$ containing fungal spores $\left(10^{6}\right.$ per $\left.\mathrm{mL}\right)$ was treated with a plasma jet for $5,10,15$, and $20 \mathrm{~min}$ or left untreated ( $0 \mathrm{~min}$, i.e., the control). Following treatment, the PDB solution $(50 \mathrm{~mL})$ was transferred to a $100 \mathrm{~mL}$ Erlenmeyer flask and incubated at $30{ }^{\circ} \mathrm{C}$ while shaken for the indicated times. The $\mathrm{H}_{2} \mathrm{O}_{2}$ concentration was measured using an Amplex ${ }^{\mathrm{TM}}$ Red Hydrogen Peroxide/Peroxidase assay kit (Molecular Probes, Eugene, OR, USA), while the $\mathrm{NO}_{X}$ levels were quantified using a QuantiChrom ${ }^{\mathrm{TM}}$ Nitric Oxide Assay Kit (BioAssay Systems, Hayward, CA, USA), according to the manufacturer's protocols. The levels of $\mathrm{NO}_{2}{ }^{-}$and $\mathrm{NO}_{3}{ }^{-}$were estimated using MQuant ${ }^{\mathrm{TM}}$ Nitrite and Nitrate test 
strips (EMD Millipore, Billerica, MA, USA). The oxidation reduction potential (ORP) was measured using an ExStik ${ }^{\mathrm{TM}}$ Model RE300 waterproof ORP meter (Extech, Nashua, NH, USA), while the $\mathrm{pH}$ was analyzed using a portable $\mathrm{pH}$ meter (Oakton Instruments, Vernon Hills, IL, USA).

\subsection{Quantitative Polymerase Chain Reaction of Secretion-Related Genes}

To measure the mRNA levels of the genes associated with protein secretion, the fungal spores (300 mL, $10^{6}$ fungal spores per $\mathrm{mL}$ ) were treated with plasma for 5, 10, 15 , and $20 \mathrm{~min}$ or left untreated (control). Following treatment, the spore suspension $(50 \mathrm{~mL})$ was transferred to a $100 \mathrm{~mL}$ Erlenmeyer flask and incubated at $30^{\circ} \mathrm{C}$ while shaken. Fungal mycelia were harvested after $48 \mathrm{~h}$ by filtering the culture through 4 layers of sterile miracloth, washed twice with deionized (DI) water, and then stored at $-80^{\circ} \mathrm{C}$ until use after removing the water. Total RNA extraction, cDNA synthesis, and RT-PCR were performed as described in a previous study [15]. The expression levels of the two putative genes involved in vesicle trafficking and transport in A. oryzae, which showed increased transcription levels post plasma treatment (SAR1 and YPT homologs) in a previous study [18], were measured using a quantitative polymerase chain reaction (qPCR) (Table 1). The relative mRNA levels were determined as a ratio compared to the expression level of a reference gene (18S

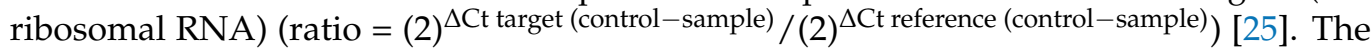
primer sequences of the putative genes are listed in Table 1. An average of six replicate measurements was considered.

Table 1. List of primers used in the quantitative polymerase chain reaction (qPCR).

\begin{tabular}{|c|c|}
\hline Genes & Primer sequences \\
\hline \multicolumn{2}{|l|}{ Vesicle trafficking and transport } \\
\hline \multirow{2}{*}{ GTPase (ER to Golgi), SAR1 homolog } & Forward-5'CGAAGTGAGCGGTATCGTTT3' \\
\hline & Reverse-5'CCСТTTCCTGTGGTCTGGTA3' \\
\hline \multirow{2}{*}{ GTPase (cis to medial Golgi), YPT1 homolog } & Forward-5'TGATGGCAAGACAGTGAAGC3' \\
\hline & Reverse-5'TTGACACCCTCAGTGGCATA3' \\
\hline \multicolumn{2}{|l|}{ Reference gene } \\
\hline \multirow{2}{*}{$18 \mathrm{~S}$ ribosomal RNA } & Forward-5'GGAAACTCACCAGGTCCAGA3' \\
\hline & Reverse-5' AGCCGATAGTCCCCCTAAGA3' \\
\hline
\end{tabular}

\subsection{Genomic DNA Analysis}

To determine the plasma-induced changes in the genome of A. oryzae, the whole genome was sequenced post plasma treatment. The fungal spores $\left(300 \mathrm{~mL}, 10^{6}\right.$ fungal spores per $\mathrm{mL}$ ) were treated with plasma for 5 and 20 min or left untreated (control). The spore suspension $(50 \mathrm{~mL})$ was transferred to a $100 \mathrm{~mL}$ Erlenmeyer flask and incubated at $30{ }^{\circ} \mathrm{C}$ while shaken for $48 \mathrm{~h}$. The fungal mycelia were harvested, washed twice with DI water, and stored at $-80{ }^{\circ} \mathrm{C}$ until use. The genomic DNA was extracted using a high-salt cetyltrimethylammonium bromide (CTAB) extraction protocol [26], and its concentration was measured using a NanoDrop ${ }^{\mathrm{TM}}$ system (Biotek Instruments, Winooski, VT, USA).

DNA library construction and sequencing were carried out by Macrogen (Seoul, Korea). For library construction, the genomic DNA was randomly fragmented, and $5^{\prime}$ and $3^{\prime}$ adapters were ligated to the DNA fragments. Adapter-ligated DNA fragments were amplified using PCR and purified on gel. The DNA library was loaded into a flow cell and captured using oligos complementary to the library adapters on the surface of the flow cell. Each DNA fragment was amplified into clonal clusters using bridge PCR amplification. Sequencing was performed using Illumina SBS (sequencing by synthesis) technology (next-generation sequencing) (Macrogen, Seoul, Korea). The sequence reads were aligned to each other to identify variants. 


\subsection{Statistical Analysis}

All data were presented as the average of 6-9 replicates. Statistical analysis of the data was performed using the Student's t-test, and statistical significance was indicated as follows: ${ }^{*}$ denotes $p<0.05$, and ${ }^{* *}$ denotes $p<0.01$.

\section{Results}

\subsection{Plasma Jet Enhances Spore Germination in A. oryzae}

After the A. oryzae spores $\left(10^{6}\right.$ spores $\left./ \mathrm{mL}, 300 \mathrm{~mL}\right)$ in PDB were treated with an NTAPP jet (Figure 1$)$, there was a significant increase $(p<0.01)$ in the number of germinated spores per $\mathrm{mL}$ of suspension in the samples treated for 5 and $10 \mathrm{~min}$ (Figure 2a). The relative germination percentage was significantly higher in the spores treated with plasma for 5 and $10 \mathrm{~min}$, compared with that in the control (0 min) (Figure 2b). An increase in germination of approximately $8 \%$ and $9 \%$ was observed in the spores treated with an NTAPP jet for 5 and $10 \mathrm{~min}$, respectively, compared with that in the control (Figure 2b).

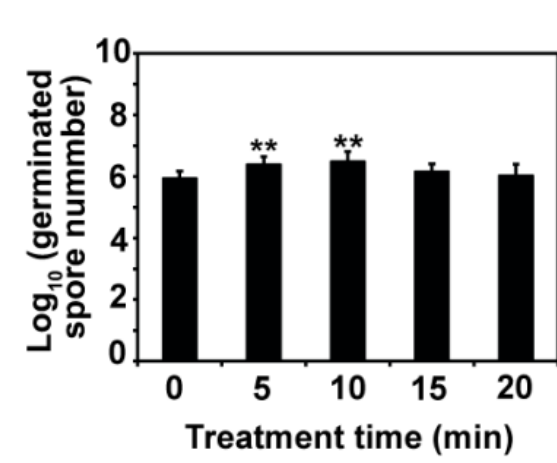

(a)

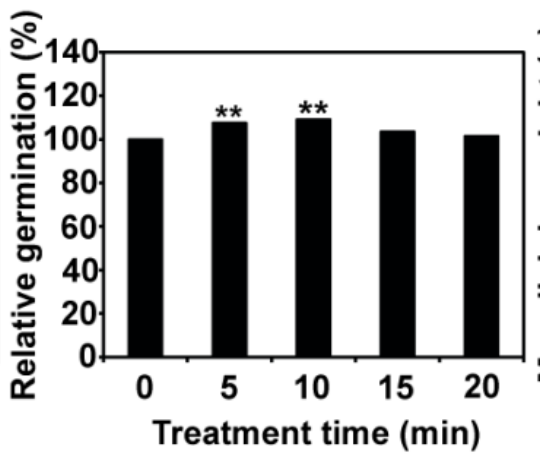

(b)

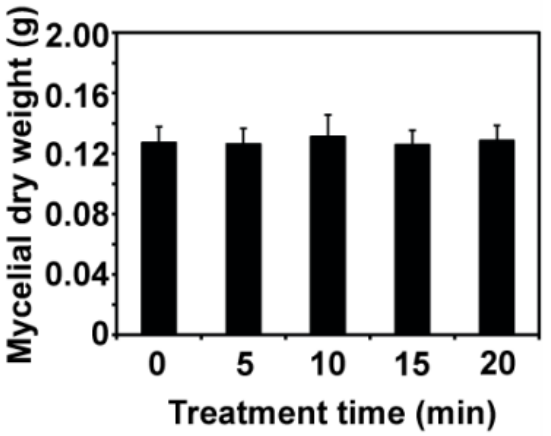

(c)

Figure 2. Spore germination and growth of $A$. oryzae post treatment with a plasma jet for 5, 10, 15, and 20 min, or without treatment $(0 \mathrm{~min}=$ control). (a) Log-scale number of germinated spores in a $1 \mathrm{~mL}$ suspension with or without treatment with a plasma jet. (b) The relative germination percentage (\%) of plasma-treated samples compared with that of the control (0 $\mathrm{min}, 100 \%)$. (c) The dry weight of the fungal mycelia grown for $48 \mathrm{~h}$ in a $50 \mathrm{~mL}$ culture. Each value is indicated as the mean and standard deviation of 6-9 replicate measurements. ${ }^{* *} p<0.01$.

Furthermore, we also investigated the effect of plasma on fungal mycelial growth after germination. No significant differences were observed in the mycelial dry masses between the control ( $0 \mathrm{~min})$ and the plasma-treated samples after $48 \mathrm{~h}$. Approximately $0.15-0.16 \mathrm{~g}$ of dry mycelial mass was obtained from the $50 \mathrm{~mL}$ culture of the control $(0 \mathrm{~min})$ and each plasma treatment time point sample (Figure 2c).

\subsection{Plasma Jet Increases $\alpha$-Amylase Secretion in A. oryzae}

The secretion of $\alpha$-amylase into PDB media by A. oryzae was analyzed by measuring the extracellular levels of total protein secretion and $\alpha$-amylase activity post plasma treatment of the fungal spores. Generally, an increase in total protein concentration in the PDB media of up to $0.029 \mathrm{mg} / \mathrm{mL}$ was observed in all samples during incubation (144 h of incubation in the $15 \mathrm{~min}$ plasma treatment group), regardless of plasma treatment (Figure 3a). However, no significant differences in total protein concentrations $(\mathrm{mg} / \mathrm{mL}$ ) were observed between the control $(0 \mathrm{~min})$ and the plasma jet-treated samples at each incubation time (24-168 h) (Figure 3a). 


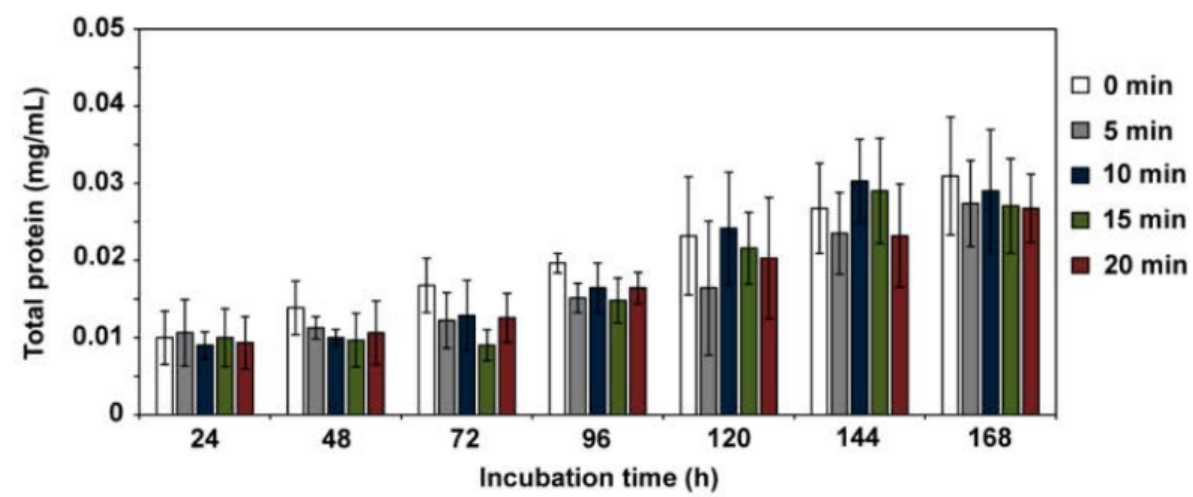

(a)

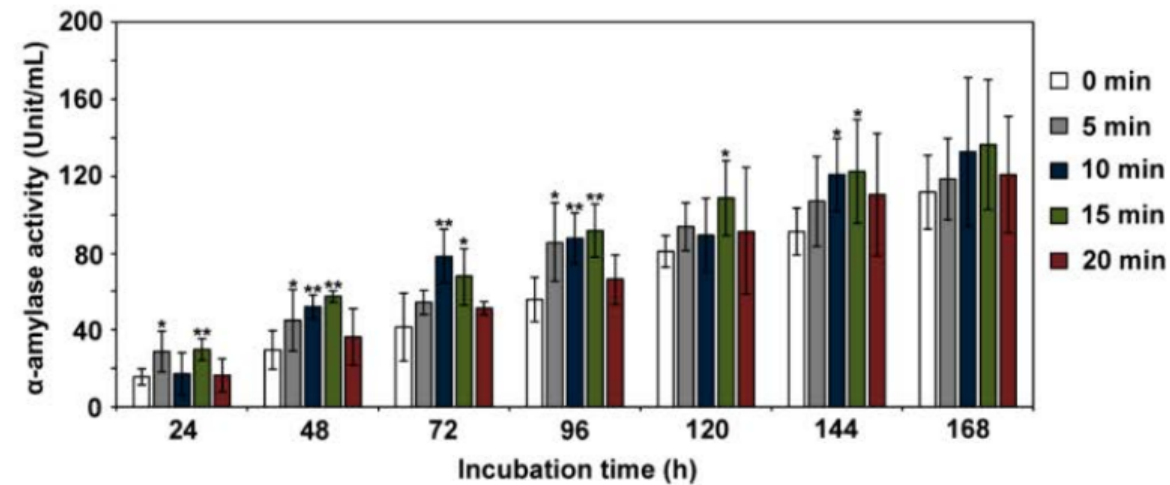

(b)

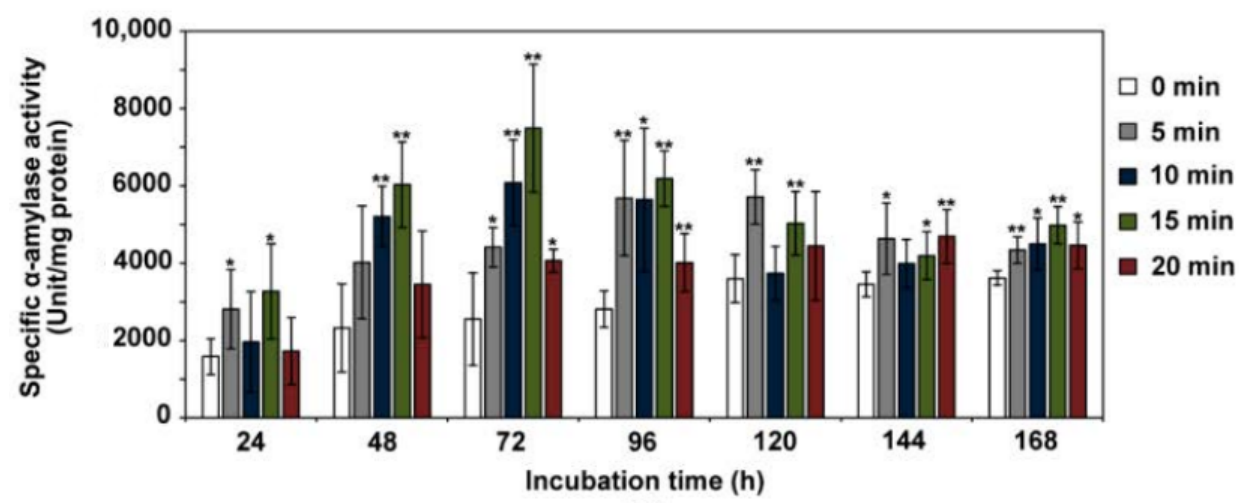

(c)

Figure 3. Total protein secretion and $\alpha$-amylase activity of $A$. oryzae during incubation post treatment with a plasma jet for $5,10,15$, and $20 \mathrm{~min}$, or without treatment $(0 \mathrm{~min}=$ control $)$. (a) The concentration of total protein in the potato dextrose broth (PDB) media $(\mathrm{mg} / \mathrm{mL})$ post incubation for the indicated time periods. (b) The $\alpha$-amylase activity (Unit/mL) detected in the PDB media post incubation for the indicated time periods. (c) The specific $\alpha$-amylase activity (Unit/mg of total protein) estimated in the PDB media post incubation for the indicated time periods. All values were calibrated with the background ( $0 \mathrm{~h}$ incubation) values. Each value is indicated as the mean and standard deviation of 6 replicate measurements. ${ }^{* *} p<0.01$ and ${ }^{*} p<0.05$.

An increase in $\alpha$-amylase activity per $\mathrm{mL}$ of PDB media was observed in all samples following incubation (Figure 3b). At all incubation times except $168 \mathrm{~h}$, the $\alpha$-amylase activity was significantly higher $(p<0.05$ and 0.01$)$ in the media of the plasma-treated samples than in that of the control (Figure $3 b$ ). A significant increase was more frequently observed under the conditions of $10 \mathrm{~min}$ and $15 \mathrm{~min}$ of plasma treatment and shorter incubation times (24-96 h) (Figure 3b). Treatment with the plasma jet for $20 \mathrm{~min}$ did 
not seem to have a significant effect on $\alpha$-amylase activity in the media over the entire incubation period (Figure $3 b$ ).

The specific activity of $\alpha$-amylase (enzyme activity expressed per milligram of total protein) in the PDB media was significantly greater $(p<0.05$ and 0.01$)$ in the plasma-treated samples than in the control over all incubation periods (Figure 3c). Plasma treatment for 20 min showed a relatively lower increase in specific activity, compared with other treatment times (Figure 3c). The highest levels of fold increase in specific activity were observed in the conditions of $10 \mathrm{~min}$ and $15 \mathrm{~min}$ of plasma treatment after incubation for $72 \mathrm{~h}$, which were approximately 2.38-fold and 2.93-fold, respectively (Figure 3c).

\subsection{Level of $\mathrm{NO}_{X}$ Species and Oxidation Reduction Potential in PDB Increases after Plasma Treatment}

Previously, we found that the plasma-induced elevation in $\alpha$-amylase secretion by A. oryzae was closely associated with the $\mathrm{NO}$ x species, particularly $\mathrm{NO}_{2}{ }^{-}$and $\mathrm{NO}_{3}{ }^{-}$ generated in the media post plasma treatment [18]. Thus, we investigated the levels of $\mathrm{NO}_{X}, \mathrm{NO}_{2}{ }^{-}, \mathrm{NO}_{3}{ }^{-}$, and $\mathrm{H}_{2} \mathrm{O}_{2}$ in the PDB media post plasma treatment. Since no suitable methods were available for measuring the levels of $\mathrm{NO}_{2}{ }^{-}$and $\mathrm{NO}_{3}{ }^{-}$in the $\mathrm{PDB}$, they were quantified in water and not PDB in our previous study [18]. In this study, however, the levels of $\mathrm{NO}_{2}{ }^{-}$and $\mathrm{NO}_{3}{ }^{-}$in the PDB media were estimated using colorimetric strips.

Following plasma treatment on day 0 , there was a slight increase $(0.074-0.093 \mathrm{mg} / \mathrm{L})$ in the levels of $\mathrm{H}_{2} \mathrm{O}_{2}$ in the PDB solution over the treatment time. However, the levels dramatically decreased after 3 and 7 days of incubation and showed no significant differences among treatment times (Figure 4a). The overall concentration of $\mathrm{NO}_{X}$ was distinctly higher than that of $\mathrm{H}_{2} \mathrm{O}_{2}$ in the PDB and continually increased with the increasing treatment time, displaying the maximum level after 20 min of treatment (1.993-2.228 mg/L) (Figure 4b). No significant changes in the levels of $\mathrm{NO}_{X}$ in the PDB were observed during incubation at each treatment time (Figure $4 \mathrm{~b}$ ). The levels of $\mathrm{NO}_{2}{ }^{-}$and $\mathrm{NO}_{3}{ }^{-}$in the $\mathrm{PDB}$ solutions were estimated from the intensity of the color that appeared on the test strips. The intensity of the pink color on the strip indicated that the $\mathrm{NO}_{2}{ }^{-}$level was generally higher than that of $\mathrm{NO}_{3}{ }^{-}$; the levels of $\mathrm{NO}_{2}{ }^{-}$and $\mathrm{NO}_{3}{ }^{-}$increased over the treatment time during incubation, with a more obvious elevation in the $\mathrm{NO}_{2}{ }^{-}$level (Figure $4 \mathrm{c}$ ). The $\mathrm{NO}_{2}{ }^{-}$concentration was estimated to be less than $5 \mathrm{mg} / \mathrm{L}$, while the $\mathrm{NO}_{3}{ }^{-}$concentration was much lower than that. There was a slight decrease in both the $\mathrm{NO}_{2}{ }^{-}$and $\mathrm{NO}_{3}{ }^{-}$levels after incubation for 3 and 7 days, as compared with that on day 0 (Figure $4 \mathrm{c}$ ).

To understand the overall oxido-reduction state of the PDB media, the ORP was measured in the PDB media during fungal culture post plasma treatment. An increase in the ORP value indicates that the PDB solution has an elevated oxidizing capability. The ORP level of the PDB media with or without fungal spores displayed a positive value of approximately $249.2 \mathrm{mV}$ before plasma treatment (Figure 5). A slight increase of up to $265.7 \mathrm{mV}$ was observed right after treatment with the NTAPP jet for 20 min (day 0) (Figure 5). During incubation, the ORP continued to increase up to $96 \mathrm{~h}$ of incubation (with a maximum ORP of $331.7 \mathrm{mV}$ at $20 \mathrm{~min}$ of treatment) and then decreased in both the plasma-treated samples and the control (Figure 5). Generally, the ORP levels were higher in the plasma-treated samples than in the control $(0 \mathrm{~min})$ at all incubation times (Figure 5). No significant differences in $\mathrm{pH}$ levels $(\mathrm{pH}=4.83-4.87)$ were observed between the plasma-treated samples and the control (0 min) (Figure 6). 


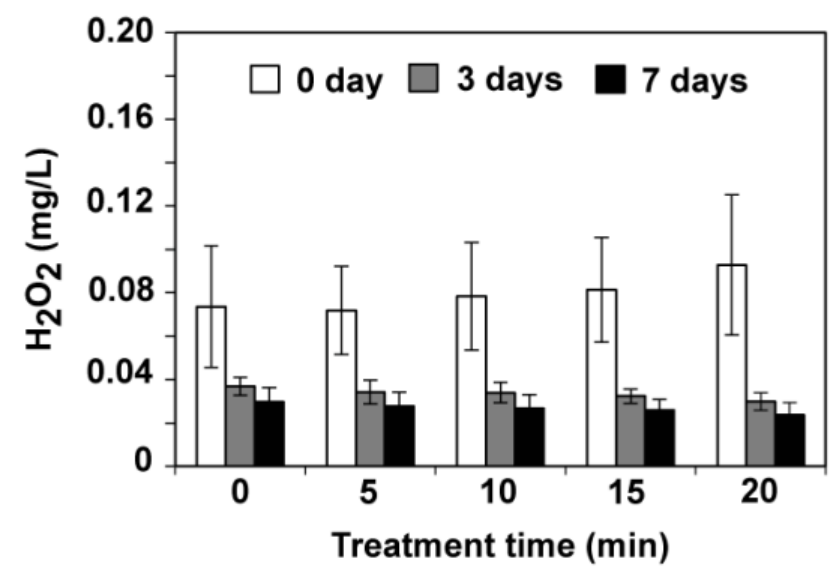

(a)

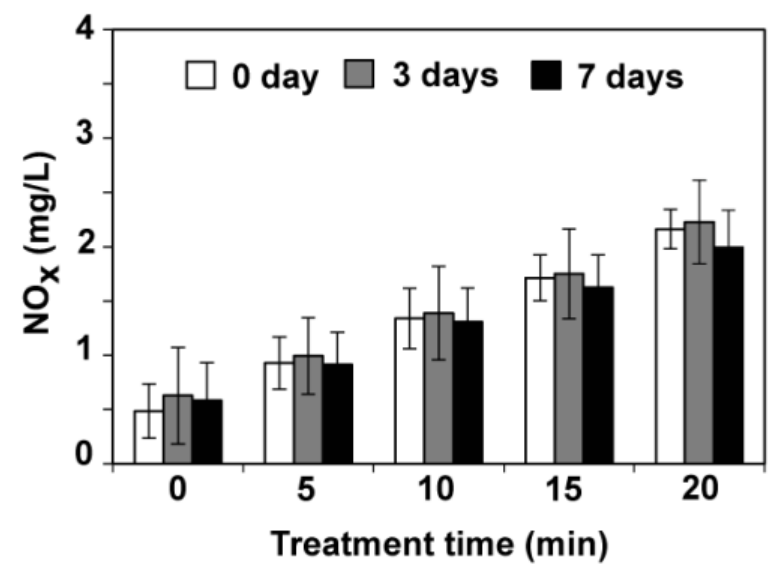

(b)
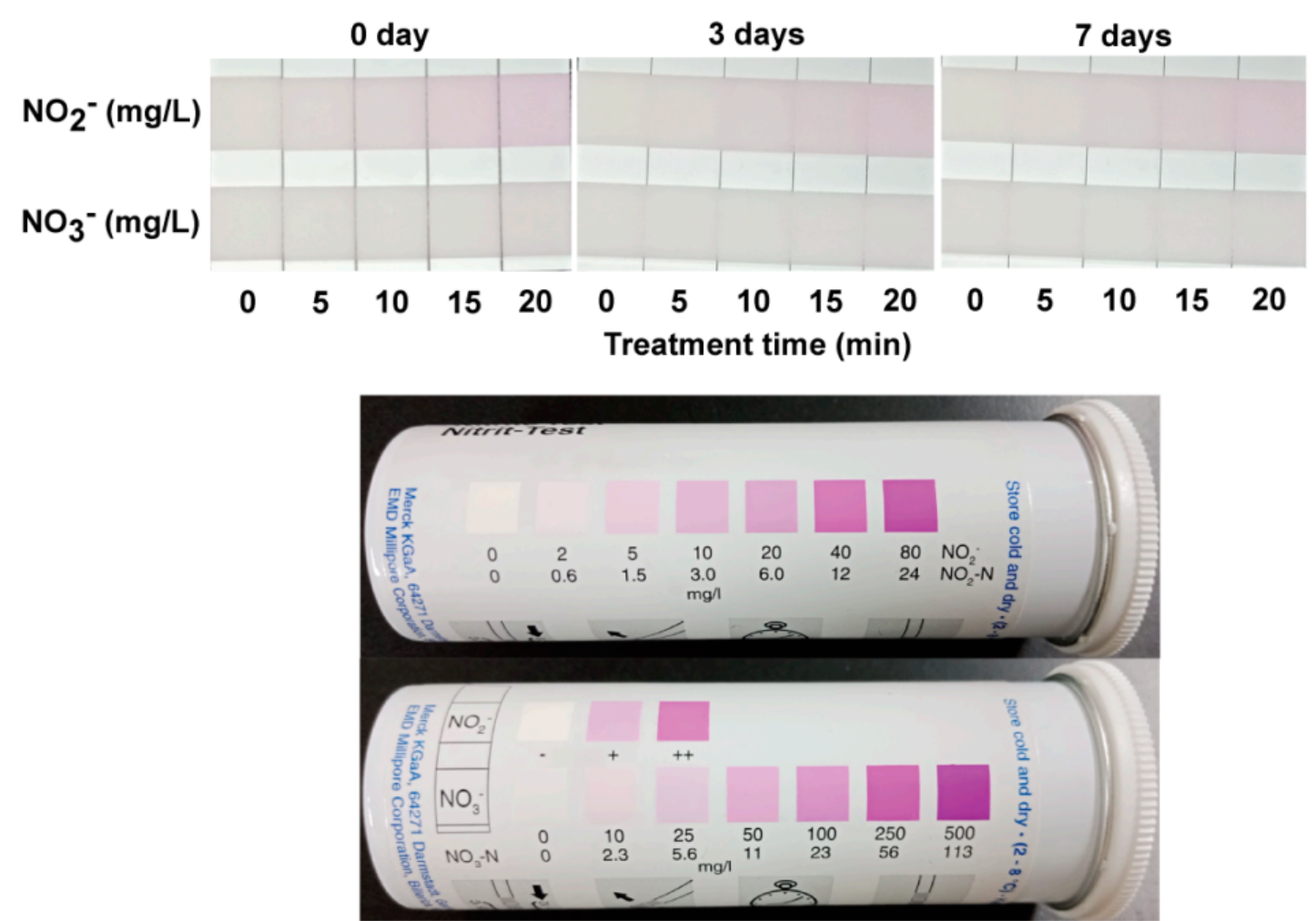

Standard of $\mathrm{NO}_{2}{ }^{-}$and $\mathrm{NO}_{3}{ }^{-}$

(c)

Figure 4. Evaluation of the reactive oxygen and nitrogen species (RONS) level in the PDB solution post plasma treatment for 5, 10, 15, and $20 \mathrm{~min}$, or without treatment ( $0 \mathrm{~min}=$ control). Following plasma treatment, the PDB was incubated for 0 , 3, and 7 days. (a) Concentration of $\mathrm{H}_{2} \mathrm{O}_{2}$. (b) Concentration of $\mathrm{NO}_{\mathbf{X}}$. (c) Color change in the $\mathrm{NO}_{2}{ }^{-}$and $\mathrm{NO}_{3}{ }^{-}$strips after soaking in the control and plasma-treated PDB (upper panel), as well as the standard concentrations of $\mathrm{NO}_{2}{ }^{-}$and $\mathrm{NO}_{3}{ }^{-}$ according to the color of the strips (bottom panel). In (a,b), each value is indicated as the mean and standard deviation of 6 replicate measurements. 


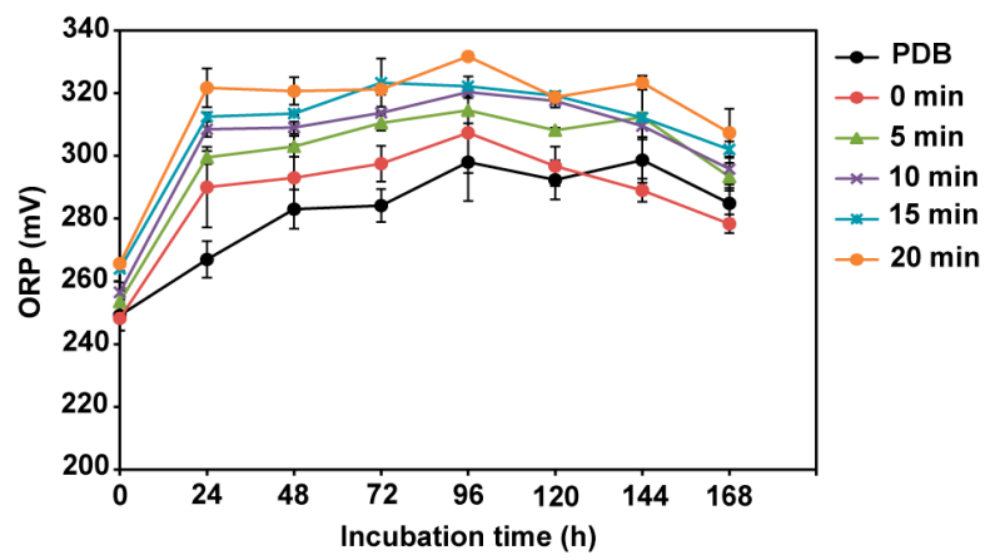

Figure 5. Oxidation reduction potential (ORP) measurements in the PDB media post plasma treatment for $5,10,15$, and $20 \mathrm{~min}$, or without treatment $(0 \mathrm{~min})$. Post plasma treatment, the fungal spores in the PDB solution were cultured for $168 \mathrm{~h}$, and the ORP was measured every $24 \mathrm{~h}$. Each value is indicated as the mean and standard deviation of 9 replicate measurements.

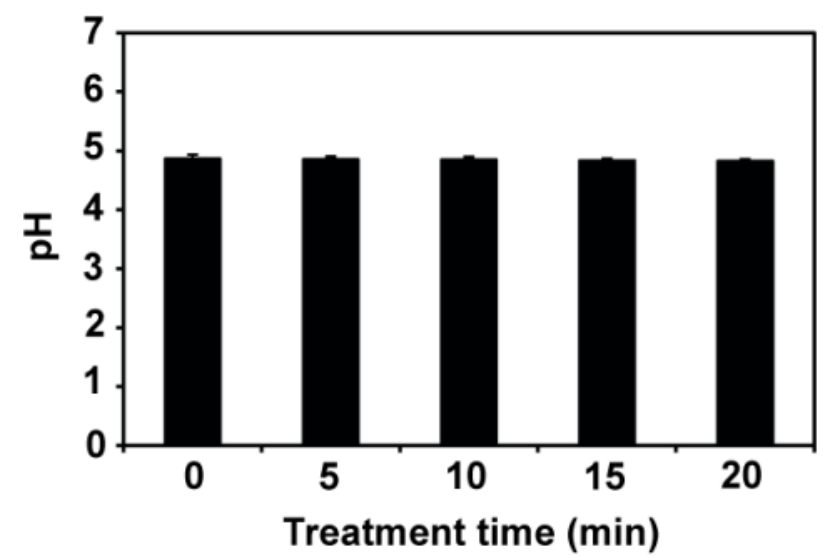

Figure 6. The $\mathrm{pH}$ measurement in the PDB media post plasma treatment of the fungal spores for 5, 10,15 , and $20 \mathrm{~min}$. Untreated ( $0 \mathrm{~min}$ ) fungal spores were used as a control. The $\mathrm{pH}$ was measured immediately after plasma treatment. Each value is indicated as the mean and standard deviation of 9 replicate measurements.

\subsection{Plasma Increases the mRNA Levels of Genes Involved in Vesicle Trafficking}

Genes homologous to SAR1 (a GTPase that controls transport from the endoplasmic reticulum to the Golgi) and YPT1 (a GTPase that controls transport from the cis to the medial Golgi), two putative genes that showed increased transcription in the plasmatreated samples in our previous study (Table 1) [18], exhibited significantly $(p<0.05$ and 0.01 ) higher levels of mRNA transcription in the fungal samples cultured for $48 \mathrm{~h}$ post plasma treatment of the spores for 15 and $20 \mathrm{~min}$ (Figure 7). This indicates that NTAPP jet treatment can activate the mRNA transcription of genes involved in vesicle trafficking of A. oryzae.

\subsection{The Effect of Plasma on the Genomic DNA of A. oryzae}

To determine the plasma-induced changes in the genomic DNA of $A$. oryzae, whole genome sequencing was performed on fungal samples cultured for $48 \mathrm{~h}$ after the spores in PDB were treated with an NTAPP jet for 5 min (short time) and 20 min (long time) or left untreated (control). The genome size of $A$. oryzae is $\sim 37 \mathrm{Mb}$ and contains 12,074 genes on 8 chromosomes $[27,28]$. In our analysis, only variations observed in most reads were considered mutations. 


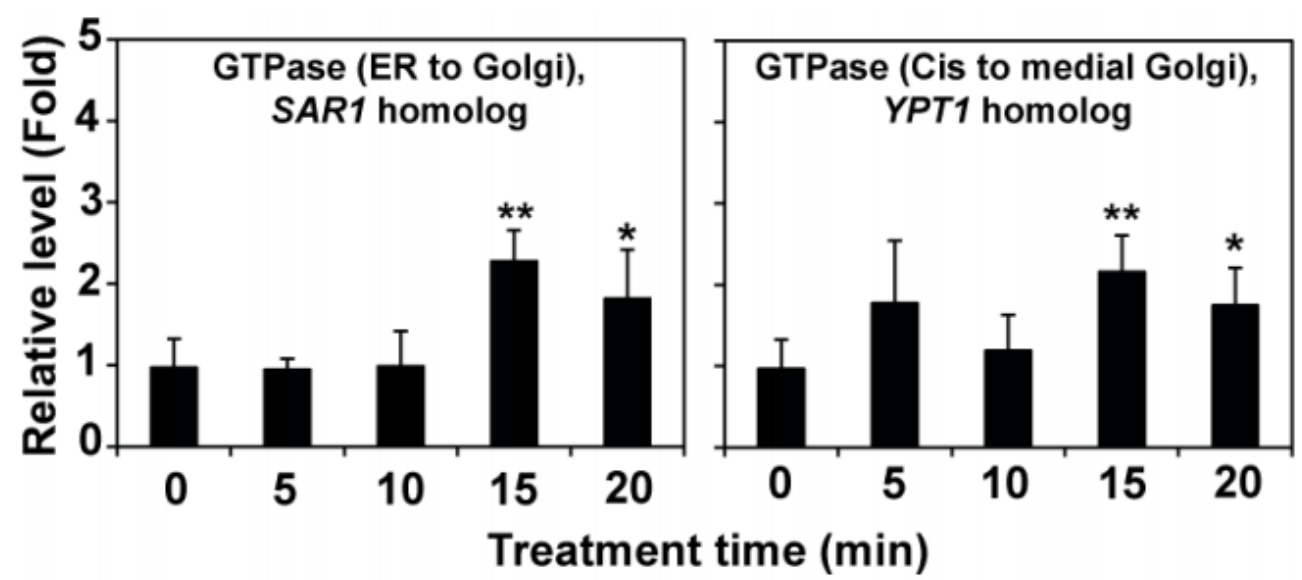

Figure 7. The mRNA levels of two putative genes involved in vesicle trafficking and transport in fungal hyphae cultured for $48 \mathrm{~h}$ post plasma treatment of the spores. Each value is indicated as the mean and standard deviation of 6 replicate measurements. ${ }^{* *} p<0.01$ and ${ }^{*} p<0.05$.

Compared to the control DNA (no plasma treatment), the genomic DNA from the plasma-treated samples (5 min and 20 min treatments) displayed approximately 0.0016$1.0017 \%$ variations in sequence (single base pair changes, deletions, and insertions) (Table 2 and Supplementary Tables S1 and S2). No dramatic differences in sequence were observed between the samples treated with plasma for $5 \mathrm{~min}$ and $20 \mathrm{~min}$, although a slightly higher mutation rate was exhibited in the samples treated for $5 \mathrm{~min}(0.0017 \%)$ than in those treated for $20 \mathrm{~min}(0.0016 \%)$ (Table 2$)$. The total mutation percentage in the exon area was about $0.0001-0.0002 \%$ in the samples treated with plasma for 5 min and $20 \mathrm{~min}$, which was lower than that in the intron area (Table 2). Missense mutations (changes in the amino acid sequence of a gene) occurred at approximately $0.00004-0.0001 \%$ positions in 17 and 10 genes upon plasma treatment for $5 \mathrm{~min}$ and $20 \mathrm{~min}$, respectively (Table 2 and Supplementary Table S3).

Table 2. Total mutations in the genomic DNA of A. oryzae after treatment with plasma for 5 min and 20 min.

\begin{tabular}{cccc}
\hline & Treatment Time $(\mathbf{m i n})$ & Mutation Position Number & Mutation (\%) \\
\hline Total mutations & 5 & 655 & 0.0017 \\
Total mutations in exons & 20 & 596 & 0.0016 \\
\hline \multirow{2}{*}{ Total mutations in introns } & 5 & 62 & 0.0002 \\
& 20 & 25 & 0.0001 \\
\hline \multirow{2}{*}{ Total missense mutations } & 5 & 593 & 0.0016 \\
\hline
\end{tabular}

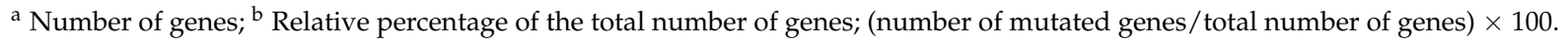

Variations in the genomic DNA appeared on each chromosomal DNA with a similar proportion (Table 3 and Supplementary Tables S1 and S2). The percentage of mutations was slightly higher in chromosome 4 than in the other chromosomes. No change was observed in the mitochondrial DNA (Table 3 and Supplementary Tables S1 and S2). 
Table 3. The percentage of mutations in each chromosome and mitochondrial genome of A. oryzae after treatment with plasma for $5 \mathrm{~min}$ and $20 \mathrm{~min}$.

\begin{tabular}{ccccccccc}
\hline & \multicolumn{2}{c}{ Mutations (\%) } & \multicolumn{2}{c}{$\begin{array}{c}\text { Mutations } \\
\text { in Exons (\%) }\end{array}$} & \multicolumn{2}{c}{$\begin{array}{c}\text { Missense } \\
\text { Mutations (\%) }\end{array}$} & \multicolumn{2}{c}{$\begin{array}{c}\text { Missense Mutationsin } \\
\text { Genes (\%) }\end{array}$} \\
\hline Treatment Time (min) & 5 & 20 & 5 & 20 & 5 & 20 & 5 & 20 \\
\hline Chromosome 1 & 0.00186 & 0.00160 & 0.00005 & 0.00000 & 0.00002 & 0.00000 & 0.04808 & 0.00000 \\
\hline Chromosome 2 & 0.00168 & 0.00115 & 0.00000 & 0.00000 & 0.00000 & 0.00000 & 0.00000 & 0.00000 \\
\hline Chromosome 3 & 0.00125 & 0.00142 & 0.00000 & 0.00000 & 0.00000 & 0.00000 & 0.00000 & 0.00000 \\
\hline Chromosome 4 & 0.00262 & 0.00309 & 0.00027 & 0.00012 & 0.00016 & 0.00010 & 0.19280 & 0.25707 \\
\hline Chromosome 5 & 0.00126 & 0.00128 & 0.00007 & 0.00013 & 0.00007 & 0.00011 & 0.13193 & 0.19789 \\
\hline Chromosome 6 & 0.00131 & 0.00138 & 0.00017 & 0.00007 & 0.00010 & 0.00002 & 0.22539 & 0.07513 \\
\hline Chromosome 7 & 0.00150 & 0.00112 & 0.00051 & 0.00024 & 0.00027 & 0.00014 & 0.31847 & 0.10616 \\
\hline Mitochondria & 0.00000 & 0.00000 & 0.00000 & 0.00000 & 0.00000 & 0.00000 & 0.00000 & 0.00000 \\
\hline
\end{tabular}

\section{Discussion}

As compared with our previous study [18], in the present study, we scaled up the number of fungal spores (from $7.5 \times 10^{7}$ to $3 \times 10^{8}$ ) and the media volume being treated (from $15 \mathrm{~mL}$ to $300 \mathrm{~mL}$ ), in addition to changing the plasma source from a micro-DBD (dielectric barrier discharge) plane-type plasma to a plasma jet. Our results demonstrated that the plasma jet, like the micro-DBD plant-type plasma used in our previous study, can promote the germination of fungal spores and $\alpha$-amylase activity in media. In addition, plasma treatment resulted in similar effects on fungal germination and enzyme activity under the scaled-up condition of the samples. Together with our previous results [15], we concluded that plasma treatment (micro-DBD plane-type plasma or plasma jet) was clearly effective for fungal spore germination, although the subsequent hyphal growth was not always enhanced. Spore germination was improved upon plasma treatment for a shorter time (5-10 min), while longer treatments did not cause significant changes. Dose-dependent activation and inactivation have been observed in mammalian cells, with increased cell proliferation being observed at low doses of plasma and cell death being observed at high doses [29].

Compared to spore germination, an increase in $\alpha$-amylase activity in the media was observed upon a relatively longer period of plasma treatment (10-15 $\mathrm{min})$. The plasmainduced enhancement effect was more dramatic during early incubation (24-96 h) than later. This may be because of the aging of the culture media and fungal cells. A promising implication from our results is that $\alpha$-amylase activity in media can be promoted by plasma treatment without using induction media for enzyme secretion, as our experiments were carried out in PBD media, not induction media. The enhanced $\alpha$-amylase activity in media may be a result of the increased secretion of enzyme protein from fungal hyphae, or the enhanced activity of $\alpha$-amylase already secreted into the media, or both. Intriguingly, we did not observe a significant difference in the total protein amount in the media between the control and the plasma-treated samples. This indicates that the enhanced $\alpha$-amylase activity in the media may not be a result of enzyme secretion from fungal hyphae. However, we did observe a slight increase in the $\alpha$-amylase protein levels in the PDB media in our previous study, and it is possible that the protein levels were possibly too small to be detected using a Bradford assay. Thus, other methods for the quantification of $\alpha$-amylase protein levels may need to be identified. The elevated secretion of enzymes upon plasma treatment has also been demonstrated by Farasat et al. [14], who showed that treatment with plasma caused an increase in the protein amount and activity of the phytase enzyme in culture media. Their study also demonstrated that plasma could enhance the activity of isolated enzymes by unfolding the tertiary structure of the enzyme slightly. Although the protein levels of the $\alpha$-amylase secreted into the media were not quantified in our study, 
a plasma jet is likely to promote the secretion of $\alpha$-amylase and the activity of secreted $\alpha$-amylase in $A$. oryzae.

The oxidative state of the PDB media seems to be closely associated with fungal activation. The highest elevation of $\alpha$-amylase activity was observed in plasma-treated samples, where PDB media exhibited ORP values of $\sim 310-320 \mathrm{mV}$. This value was higher than that of the control ( $0 \mathrm{~min}, 290-305 \mathrm{mV}) . \mathrm{H}_{2} \mathrm{O}_{2}$ and other reactive oxygen species generated upon plasma treatment may have contributed to the elevation in the ORP level in the PDB media, because $\mathrm{H}_{2} \mathrm{O}_{2}$ can behave as an oxidant or a reductant in redox reactions [30]. Our results suggest that a certain level of oxidizing conditions outside the cells (310-320 mV in our case) may be needed for activation of the enzyme or enzyme secretion. Studies have shown that increased ORP values in plasma-treated water have a high impact on the oxidizing capacity and anti-microbial potential [31-34]. However, our study demonstrated that microbial activation can also be induced under certain levels of the ORP. As observed in our previous study, $\mathrm{NO}_{X}$ was stably detected in the PDB media during incubation post plasma treatment in this study as well. This indicates that $\mathrm{NO}_{X}$ may be crucial for enhancing enzyme activity. In addition, the long-lived species of $\mathrm{NO}_{2}{ }^{-}$and $\mathrm{NO}_{3}{ }^{-}$were detected in the PDB media upon plasma treatment, indicating that these could be major players in the plasma-mediated activation of the enzyme or enzyme secretion. Although $\mathrm{NO}_{X}$ levels were higher in the plasma-treated samples, no significant changes were observed in the $\mathrm{pH}$ levels, which were close to the optimal $\mathrm{pH}$ range of 5.0-6.0, which is suitable for $\alpha$-amylase enzyme production by Aspergillus sp. in a submerged fermentation culture [1].

Treatment with a plasma jet caused a small portion of variations in the genomic DNA of $A$. oryzae in our study. Some of these variations occurred in the protein coding region. The plasma treatment time did not seem to affect the extent of genetic variations because similar levels of variation were observed upon plasma treatment for $5 \mathrm{~min}$ and $20 \mathrm{~min}$. The soft rays and free radicals generated from NTAPP are known to damage DNA and RNA with increasing treatment times $[35,36]$. This may lead to a mutational change in the sequence. In addition, recent studies using $A$. oryzae and C. albicans have demonstrated that plasma-induced mutations enhance the activity of salt-tolerant proteases and xylose reductases without the occurrence of mutations in those enzyme genes themselves [16,17]. Since most of the genes found to be mutated upon plasma treatment in our study were uncharacterized, it is not clear whether the increased activity of $\alpha$-amylase resulted from mutations or not. However, if the mutations that result in amino acid changes in genes are not critical for modifying the protein tertiary structure, the protein function can remain unaltered. In this case, plasma-induced mutations may not be related to the elevation of the extracellular activity of $\alpha$-amylase in A. oryzae. Furthermore, a recent study on human stem cells demonstrates that NTAPP can induce epigenetic modifications and activate the expression of genes involved in cell differentiation [37]. Likewise, plasma treatment can possibly induce the epigenetic changes that activate the expression of genes involved in the metabolic pathways, germination, and secretion of enzymes in $A$. oryzae.

\section{Conclusions}

In this study, we demonstrated that the scaled-up treatment of $A$. oryzae spores with an NTAPP jet could enhance the spore germination and activity of $\alpha$-amylase in the PDB media at the hyphal stage. Different treatment times were required for the highest elevation of spore germination and enzyme activity. These results indicate that similar plasma effects on fungal activation, as observed in our previous study, were obtained with a large sample size and different plasma sources. The enhanced activity of $\alpha$-amylase in the PDB media is likely to be associated with the levels of the ORP and $\mathrm{NO}_{X}$ in the media. This suggests that the levels of the ORP and $\mathrm{NO}_{X}$ in the media resulting from plasma treatment can serve as standards for assessing microbial activation. Plasma jet treatment induced mutational variations in the genomic DNA of $A$. oryzae, but it remained to be elucidated whether these genetic changes might affect enzyme secretion. 
Supplementary Materials: The following are available online at https:/ / www.mdpi.com/2076-341 7/11/2/691/s1: Table S1: total mutations in 5 min ofplasma treatment; Table S2: total mutations in 20 min of plasma treatment; and Table S3: missense mutations in 5 and 20 min of plasma treatment.

Author Contributions: Conceptualization, M.V. and G.P.; methodology, M.V. and E.H.C.; formal analysis, M.V. and G.P.; investigation, M.V.; resources, E.H.C.; data curation, M.V. and G.P.; writingoriginal draft preparation, M.V.; writing-review and editing, G.P.; supervision, G.P.; project administration, G.P.; funding acquisition, G.P. All authors have read and agreed to the published version of the manuscript.

Funding: This work was supported by the R\&D program of Plasma Advanced Technology for Agriculture and Food (Plasma Farming) through the National Fusion Research Institute of Korea (NFRI, funded by governmental funds). This work was partially supported by the National Research Foundation of Korea (NRF) (2016R1D1A1B03934922 and 2020R1F1A107094211).

Institutional Review Board Statement: Not applicable.

Informed Consent Statement: Not applicable.

Data Availability Statement: The data presented in this study are available in article and supplementary material.

Acknowledgments: We would like to thank the Korean Agriculture Type Collection at the National Agrobiodiversity Center (Wanju-gun, Jeollabuk-do, Republic of Korea) for kindly providing us with the A. oryzae strains. We also thank Editage (www.editage.co.kr) for the English language editing.

Conflicts of Interest: The authors declare no conflict of interest.

\section{References}

1. Sundarram, A.; Murthy, T.P.K. $\alpha$-Amylase Production and Applications: A Review. Appl. Environ. Microbiol. 2014,2 , 166-175. [CrossRef]

2. Abdullah, R.; Haq, I.; Iftikhar, T.; Khattak, Z. Random mutagenesis for enhanced production of alpha amylase by Aspergillus Oryzae IIB-30. Pak. J. Bot. 2013, 45, 269-274.

3. Raveendran, S.; Parameswaran, B.; Ummalyma, S.B.; Abraham, A.; Mathew, A.K.; Madhavan, A.; Rebello, S.; Pandey, A. Applications of Microbial Enzymes in Food Industry. Food Technol. Biotechnol. 2018, 56, 16-30. [CrossRef] [PubMed]

4. Deckers, M.; Deforce, D.; Fraiture, M.-A.; Roosens, N.H.C. Genetically Modified Micro-Organisms for Industrial Food Enzyme Production: An Overview. Foods 2020, 9, 326. [CrossRef] [PubMed]

5. Mizuno, A. Industrial applications of atmospheric non-thermal plasma in environmental remediation. Plasma Phys. Control. Fusion 2007, 49, A1. [CrossRef]

6. Weltmann, K.D.; Von Woedtke, T. Plasma medicine-Current state of research and medical application. Plasma Phys. Control. Fusion 2016, 59, 014031. [CrossRef]

7. Hati, S.; Patel, M.; Yadav, D. Food bioprocessing by non-thermal plasma technology. Curr. Opin. Food Sci. $2018,19,85-91$. [CrossRef]

8. Mandal, R.; Singh, A.; Pratap Singh, A. Recent developments in cold plasma decontamination technology in the food industry. Trends Food Sci. Technol. 2018, 80, 93-103. [CrossRef]

9. Bernhardt, T.; Semmler, M.L.; Schäfer, M.; Bekeschus, S.; Emmert, S.; Boeckmann, L. Plasma Medicine: Applications of Cold Atmospheric Pressure Plasma in Dermatology. Oxid. Med. Cell. Longev. 2019, 2019, 3873928. [CrossRef]

10. Sakudo, A.; Yagyu, Y.; Onodera, T. Disinfection and Sterilization Using Plasma Technology: Fundamentals and Future Perspectives for Biological Applications. Int. J. Mol. Sci. 2019, 20, 5216. [CrossRef]

11. Simoncicova, J.; Krystofova, S.; Medvecka, V.; Durisova, K.; Kalinakova, B. Technical applications of plasma treatments: Current state and perspectives. Appl. Microbiol. Biotechnol. 2019, 103, 5117-5129. [CrossRef] [PubMed]

12. Zhao, Y.M.; Patange, A.; Sun, D.W.; Tiwari, B. Plasma-activated water: Physicochemical properties, microbial inactivation mechanisms, factors influencing antimicrobial effectiveness, and applications in the food industry. Compr. Rev. Food Sci. Food Saf. 2020, 19, 3951-3979. [CrossRef] [PubMed]

13. Lopez, M.; Calvo, T.; Prieto, M.; Mugica-Vidal, R.; Muro-Fraguas, I.; Alba-Elias, F.; Alvarez-Ordonez, A. A Review on Non-thermal Atmospheric Plasma for Food Preservation: Mode of Action, Determinants of Effectiveness, and Applications. Front. Microbiol. 2019, 10, 622. [CrossRef]

14. Farasat, M.; Arjmand, S.; Ranaei Siadat, S.O.; Sefidbakht, Y.; Ghomi, H. The effect of non-thermal atmospheric plasma on the production and activity of recombinant phytase enzyme. Sci. Rep. 2018, 8, 16647. [CrossRef] [PubMed]

15. Veerana, M.; Lim, J.-S.; Choi, E.-H.; Park, G. Aspergillus oryzae spore germination is enhanced by non-thermal atmospheric pressure plasma. Sci. Rep. 2019, 9, 11184. [CrossRef] [PubMed] 
16. Zhang, C.; Qin, J.; Dai, Y.; Mu, W.; Zhang, T. Atmospheric and room temperature plasma (ARTP) mutagenesis enables xylitol over-production with yeast Candida tropicalis. J. Biotechnol. 2019, 296, 7-13. [CrossRef]

17. Gao, X.; Liu, E.; Yin, Y.; Yang, L.; Huang, Q.; Chen, S.; Ho, C.-T. Enhancing Activities of Salt-Tolerant Proteases Secreted by Aspergillus oryzae Using Atmospheric and Room-Temperature Plasma Mutagenesis. J. Agric. Food Chem. 2020, 68, $2757-2764$. [CrossRef]

18. Veerana, M.; Mitra, S.; Ki, S.-H.; Kim, S.-M.; Choi, E.-H.; Lee, T.; Park, G. Plasma-mediated enhancement of enzyme secretion in Aspergillus oryzae. Microb. Biotechnol. 2020. [CrossRef]

19. Meneghel, L.; Reis, G.P.; Reginatto, C.; Malvessi, E.; Da Silveira, M.M. Assessment of pectinase production by Aspergillus oryzae in growth-limiting liquid medium under limited and non-limited oxygen supply. Process. Biochem. 2014, 49, 1800-1807. [CrossRef]

20. Carevic, M.; Velickovic, D.; Stojanovic, M.; Milosavic, N.; Rogniaux, H.; Ropartz, D.; Bezbradica, D. Insight in the regioselective enzymatic transgalactosylation of salicin catalyzed by $\beta$-galactosidase from Aspergillus oryzae. Process. Biochem. 2015, 50, 782-788. [CrossRef]

21. Porfirif, M.C.; Milatich, E.J.; Farruggia, B.M.; Romanini, D. Production of alpha-amylase from Aspergillus oryzae for several industrial applications in a single step. J. Chromatogr. B 2016, 1022, 87-92. [CrossRef] [PubMed]

22. Adhikari, B.; Adhikari, M.; Ghimire, B.; Adhikari, B.C.; Park, G.; Choi, E.H. Cold plasma seed priming modulates growth, redox homeostasis and stress response by inducing reactive species in tomato (Solanum lycopersicum). Free Radic. Biol. Med. 2020, 156, 57-69. [CrossRef] [PubMed]

23. Sahnoun, M.; Bejar, S.; Sayari, A.; Triki, M.A.; Kriaa, M.; Kammoun, R. Production, purification and characterization of two $\alpha$-amylase isoforms from a newly isolated Aspergillus Oryzae strain S2. Process. Biochem. 2012, 47, 18-25. [CrossRef]

24. Bernfeld, P. Amylases, $\alpha$ and $\beta$. Meth. Enzymol. 1955, 1, 149-158.

25. Livak, K.J.; Schmittgen, T.D. Analysis of Relative Gene Expression Data Using Real-Time Quantitative PCR and the 2- $\Delta \Delta C \mathrm{~T}$ Method. Methods 2001, 25, 402-408. [CrossRef]

26. Inglis, P.W.; Pappas, M.d.C.R.; Resende, L.V.; Grattapaglia, D. Fast and inexpensive protocols for consistent extraction of high quality DNA and RNA from challenging plant and fungal samples for high-throughput SNP genotyping and sequencing applications. PLoS ONE 2018, 13, e0206085. [CrossRef]

27. Machida, M.; Asai, K.; Sano, M.; Tanaka, T.; Kumagai, T.; Terai, G.; Kusumoto, K.-I.; Arima, T.; Akita, O.; Kashiwagi, Y.; et al. Genome sequencing and analysis of Aspergillus oryzae. Nature 2005, 438, 1157-1161. [CrossRef]

28. Kitamoto, K. Cell biology of the Koji mold Aspergillus oryzae. Biosci. Biotechnol. Biochem. 2015, 79, 863-869. [CrossRef] [PubMed]

29. Kalghatgi, S.; Kelly, C.M.; Cerchar, E.; Torabi, B.; Alekseev, O.; Fridman, A.; Friedman, G.; Azizkhan-Clifford, J. Effects of Non-Thermal Plasma on Mammalian Cells. PLoS ONE 2011, 6, e16270. [CrossRef] [PubMed]

30. Lukes, P.; Locke, B.; Brisset, J.-L. Aqueous-Phase Chemistry of Electrical Discharge Plasma in Water and in Gas-Liquid Environments. In Plasma Chemistry and Catalysis in Gases and Liquids; Parvulescu, V.I., Magureanu, M., Lukes, P., Eds.; Wiley-VCH: Weinheim, Germany, 2012; pp. 243-308.

31. Tian, Y.; Ma, R.; Zhang, Q.; Feng, H.; Liang, Y.; Zhang, J.; Fang, J. Assessment of the Physicochemical Properties and Biological Effects of Water Activated by Non-thermal Plasma Above and Beneath the Water Surface. Plasma Processes Polym. 2015, 12, 439-449. [CrossRef]

32. Zhang, Q.; Ma, R.; Tian, Y.; Su, B.; Wang, K.; Yu, S.; Zhang, J.; Fang, J. Sterilization Efficiency of a Novel Electrochemical Disinfectant against Staphylococcus aureus. Environ. Sci. Technol. 2016, 50, 3184-3192. [CrossRef] [PubMed]

33. Xu, Y.; Tian, Y.; Ma, R.; Liu, Q.; Zhang, J. Effect of plasma activated water on the postharvest quality of button mushrooms, Agaricus bisporus. Food Chem. 2016, 197, 436-444. [CrossRef] [PubMed]

34. Thirumdas, R.; Kothakota, A.; Annapure, U.; Siliveru, K.; Blundell, R.; Gatt, R.; Valdramidis, V.P. Plasma activated water (PAW): Chemistry, physico-chemical properties, applications in food and agriculture. Trends Food Sci. Technol. 2018, 77, 21-31. [CrossRef]

35. Zhang, X.; Zhang, X.-F.; Li, H.-P.; Wang, L.-Y.; Zhang, C.; Xing, X.-H.; Bao, C.-Y. Atmospheric and room temperature plasma (ARTP) as a new powerful mutagenesis tool. Appl. Microbiol. Biotechnol. 2014, 98, 5387-5396. [CrossRef]

36. Zhang, N.; Jiang, J.-C.; Yang, J.; Wei, M.; Zhao, J.; Xu, H.; Xie, J.-C.; Tong, Y.-J.; Yu, L. Citric Acid Production from Acorn Starch by Tannin Tolerance Mutant Aspergillus niger AA120. Appl. Biochem. Biotechnol. 2019, 188, 1-11. [CrossRef]

37. Park, J.; Suh, D.; Tang, T.; Lee, H.J.; Roe, J.-S.; Kim, G.C.; Han, S.; Song, K. Non-thermal atmospheric pressure plasma induces epigenetic modifications that activate the expression of various cytokines and growth factors in human mesoderm-derived stem cells. Free Radic. Biol. Med. 2020, 148, 108-122. [CrossRef] 